ISSN (PRINT) : 2686-2409 ISSN (ONLINE) : 2686-6277

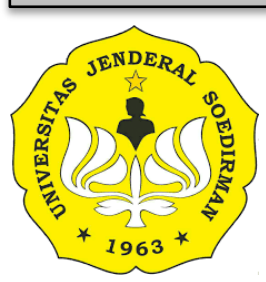

SOEDIRMAN ECONOMICS EDUCATION JOURNAL

http://jos.unsoed.ac.id/index.php/seej/

\title{
PENGARUH MANAJEMEN KELAS, KESIAPAN BELAJAR DAN PEMANFAATAN INTERNET TERHADAP PRESTASI BELAJAR EKONOMI SISWA KELAS X IPS SMA NEGERI 4 PURWOKERTO
}

\author{
Siti Mutmainah1, Bambang Sunarko² ${ }^{2}$ Eling Purwanto Jati ${ }^{3}$ \\ 1,2,3 Fakultas Ekonomi dan Bisnis, Universitas Jenderal Soedirman, Indonesia \\ Email corresponding author :alqmutmainah@gmail.com
}

\begin{abstract}
Abstrak
Penelitian ini merupakan penelitian dengan pendekatan deksriptif kuantitatif yang bertujuan untuk mengetahui pengaruh manajemen kelas, kesiapan belajar dan pemanfaatan internet terhadap prestasi belajar ekonomi siswa kelas X IPS SMA Negeri 4 Purwokerto. Populasi dalam penelitian ini yaitu seluruh siswa kelas X IPS SMA Negeri 4 Purwokerto sebanyak 141 siswa. Teknik pengambilan sampling yaitu simple randomsampling dengan jumlah sampel sebanyak 105 responden.

Teknik analisis data yang digunakan dalam penelitian ini adalah analisis regresi linear berganda. Penelitian ini menghasilkan suatu kesimpulan: 1) Manajemen kelas berpengaruh positif terhadap prestasi belajar ekonomi siswa kelas X IPS SMA Negeri 4 Purwokerto; 2) Kesiapan belajar berpengaruh positif terhadap prestasi belajar ekonomi siswa kelas X IPS SMA Negeri 4 Purwokerto; 3) Pemanfaatan internet berpengaruh positif terhadap prestasi belajar ekonomi siswa kelas X IPS SMA Negeri 4 Purwokerto; 4) Manajemen kelas, kesiapan belajar dan pemanfaatan internet secara simultan berpengaruh terhadap prestasi belajar ekonomi siswa kelas X IPS SMA Negeri 4 Purwokerto.
\end{abstract}

Kata kunci : Internet, Kesiapan, Manajemen Kelas, Prestasi

\begin{abstract}
This research is a quantitative descriptive study that aims to determine the effect of class management, learning readiness and internet utilization on economic learning achievement of Social Sciences X grade students at SMA 4 Purwokerto. The population in this study were all students of class X IPS SMA Negeri 4 Purwokerto as many as 141 students. The sampling technique is simple random sampling with a total sample of 105 respondents.

The data analysis technique used in this study is multiple linear regression analysis. This study yields a conclusion: 1) Class management has a positive effect on economic learning achievement of Social Sciences class X students of SMA 4 Purwokerto; 2) Readiness of learning has a positive effect on economic learning achievement of Social Sciences class X students of SMA 4 Purwokerto; 3) The use of the internet has a positive effect on the economic learning achievement of Social Sciences class X students at SMA 4 Purwokerto; 4) Class management, learning readiness and the uses of the internet simultaneously have an effect on the economic learning achievement of Social Sciences class X students of SMA 4 Purwokerto.
\end{abstract}

Keywords: Internet, Readiness, Class Management,, Achievement 


\section{PENDAHULUAN}

Sektor pendidikan berusaha untuk mencetak kualitas sumber daya manusia yang dibutuhkan dalam pencapaian pembangunan nasional. Melalui pendidikan diajarkan nilai-nilai kebaikan dan potensi sumber daya manusia dapat dikembangkan. Sekolah merupakan tempat proses pendidikan itu dilakukan.

Salah satu indikator keberhasilan sekolah dalam menghasilkan lulusan yang berkualitas dapat dilihat melalui prestasi belajar yang dihasilkan peserta didik. Sukmadinata (2009:102-103) mengungkapkan prestasi belajar (achievement) yaitu pemekaran atau pengembangan suatu keterampilan dasar yang dimiliki seseorang dan direpresentasikan melalui huruf maupun angka.

Prestasi belajar digunakan untuk mengukur pencapaian keberhasilan seseorang setelah belajar yang dipengaruhi oleh beberapa faktor. Menurut Slameto (2010:54-72) faktor-faktor yang mempengaruhi prestasi belajar yaitu faktor intern dan faktor ekstern. Faktor intern merupakan komponen yang sumbernya berasal dari peserta didik yang mempengaruhi kemampuan dalam belajarnya mencakup jasmaniah (kesehatan dan cacat tubuh), psikologis (inteligensi, perhatian, minat, bakat, kematangan, kesiapan serta motif) dan kelelahan (kelelahan jasmani serta kelelahan rohani). Sementara itu, faktor ekstern adalah komponen yang sumbernya dari luar diri peserta didik yang mempengaruhi prestasi belajar yaitu keluarga (cara orang tua mendidik, hubungan antar anggota keluarga, suasana tempat tinggal, kondisi ekonomi keluarga, latar belakang kebudayaan serta pengertian orang tua), masyarakat (mass media, teman sebaya, aktivitas siswa dalam masyarakat serta bentuk kehidupan masyarakat) dan sekolah (kurikulum, metode mengajar, disiplin sekolah, hubungan guru dengan siswa, alat pelajaran, hubungan antar siswa, waktu sekolah, keadaan gedung, metode belajar, standar pelajaran di atas ukuran dan tugas rumah).

Djamarah dan Zain (2010:194) menyatakan bahwa tinggi rendahnya prestasi belajar dapat dilihat dari kemampuan guru dalam melakukan manajemen kelas. Menurut Tim Dosen Administrasi Pendidikan (2011:106) manajemen kelas adalah keseluruhan upaya guna menciptakan suasana pembelajaran yang kondusif serta memotivasi siswa agar belajar dengan baik selaras dengan potensi yang dimilikinya. Seorang guru seharusnya dapat menerapkan manajemen kelas yang baik agar tercapainya tujuan dalam belajar. Untuk dapat meraih prestasi belajar siswa yang memuaskan diperlukan proses pembelajaran yang tepat yaitu diwujudkan dengan cara melakukan manajemen kelas yang baik. Namun, Santrock (2014:211) menyatakan, "Di kalangan pendidikan, merupakan hal umum mengatakan bahwa tidak ada yang memerhatikan manajemen kelas yang baik sampai hal tersebut tidak ada". Menurut Khofifah (2016) dalam penelitiannya membuktikan bahwa manajemen kelas memiliki pengaruh yang positif terhadap prestasi belajar. Lain halnya penelitian Supriyati (2015) yang mengungkapkan tidak adanya 
pengaruh signifikan manajemen atau kemampuan pengelolaan kelas dalam aktivitas pembelajaran danpengaruhnya terhadap prestasi akademik.

Slameto (2010:59) menyatakan bahwa prestasi belajar siswa juga dipengaruhi oleh faktor intern salah satunya adalah kesiapan belajar. Kesiapan merupakan segala keadaan individu yang mempersiapkan diri untuk memberikan tanggapan dengan gaya tertentu pada situasi yang dihadapi (Slameto, 2010:113). Proses belajar harus memperhatikan adanya kesiapan belajar. Hal ini dikarenakan jika dalam proses belajar terdapat kesiapan, maka siswa semakin mudah menerima pelajaran. Selain itu, kesiapan menimbulkan dorongan kepada peserta didik untuk menanggapi dengan positif, kondisi itu yang akan mempengaruhi prestasi belajar yang dicapai. Selaras dengan penelitian Bujuri (2015) yang menunjukkan ada pengaruh yang positif dan signifikan kesiapan belajar terhadap prestasi belajar. Berbeda dengan penelitian Hotimah (2012)yang meyebutkan bahwatidak ada pengaruh kesiapan belajar terhadap prestasi belajar.

Selain faktor manajemen kelas dan kesiapan belajar, faktor lainnya yang mempengaruhi prestasi belajar ialah pemanfaatan internet. Halik (2013:6) menyatakan bahwa internet merupakan media digital yang menjadi bagian dari mass media. Mass media merupakan salah satu faktor yang dapat mempengaruhi prestasi belajar (Slameto, 2010:70). Menurut Sanjaya (2012:216) internet adalah sistem yang menghubungkan jaringan komputer menjadi satu kesatuan. Dalam pembelajaran, internet sangat penting bagi siswa karena dengan memanfaatkan internet dengan baik, siswa dapat meningkatkan pengetahuannya bagi keberhasilannya dalam belajar. Hal ini disebabkan dengan adanya perkembangan zaman yang semakin maju, serta kurikulum pendidikan yang semakin berkembang mengharuskan siswa untuk aktif dan kreatif dalam mencari bahan pembelajaran yang akhirnya dapat menimbulkan minat siswa dalam menggunakan internet. Menurut penelitian Utami (2012) mengungkapkan pemanfaatan internet berpengaruh positif terhadap prestasi belajar siswa. Lain halnya penelitian Samiaji(2009) yang menunjukan bahwa tidak ada pengaruh pemanfaatan internet terhadap prestasi belajar.

Peneliti melakukan observasi awal di tempat penelitian yaitu SMAN 4 Purwokerto dan menerima informasi mengenai prestasi belajar ekonomi yang tertuang dalam tabel 1 . Tabel 1 memaparkan informasi bahwa dari 141 siswa terdapat 77 siswa atau 54,61\% yang prestasi belajarnya pada mata pelajaran ekonomi masih di bawah nilai KKM yang besarnya 75, sedangkan siswa yang prestasi belajarnya sudah berhasil meraih atau melebihi nilai KKM hanya 64 siswa atau $45,39 \%$.Hal ini menunjukkan bahwa prestasi belajar siswa pada mata pelajaran ekonomi masih belum optimal atau masih rendah dan terdapat faktor yang mempengaruhi prestasi belajar mencakup faktor intern yang sumbernya dari diri peserta didik dan faktor ekstern yang berasal dari luarpeserta didik.

Tabel 1. Data Nilai Ulangan Harian Ekonomi Siswa Kelas X IPS 


\begin{tabular}{ccccc}
\hline No & Kelas & \multicolumn{2}{c}{ Interval Nilai } & Jumlah \\
& & $<75$ & $>75$ & \\
\hline 1 & X IPS 1 & 18 & 18 & 36 \\
2 & X IPS 2 & 25 & 10 & 35 \\
3 & X IPS 3 & 16 & 20 & 36 \\
4 & X IPS 4 & 18 & 16 & 34 \\
\hline & Total & 77 & 64 & 141 \\
\hline & Presentase & $54,61 \%$ & $45,39 \%$ & $100 \%$
\end{tabular}

Sumber: Dokumentasi datftar nilai mata pelajaran ekonomi siswa kelas X IPS SMA Negeri 4 Purwokerto tahun ajaran 2018/2019.

Pada saat proses belajar mengajar di kelas tidak jarang ditemui suatu masalah. Permasalahan ini terjadi di setiap sekolah, terkhusus di SMAN 4 Purwokerto. Masalah yang terjadi yaitu manajemen kelas yang dilakukan guru belum optimal, sehingga masih ada siswa yang tidak memperhatikan penjelasan materi yang sedang disampaikan guru seperti berbincang-bincang dengan temannya. Selain itu, siswa kurang memberikan respon atau jawaban atas pertanyaanpertanyaan yang diajukan guru karena siswa tidak membaca dan mempelajari buku materi pelajaran terlebih dahulu. Hal ini mengindikasikan kurangnya kesiapan belajar yang ada di dalam diri siswa.

Di samping itu, SMA Negeri 4 Purwokerto adalah sekolah yang berupaya untuk mengoptimalkan pemanfaatan jaringan internet. Oleh karena itu, sekolah memfasilitasi siswa dengan jaringan internet yang memadai yaitu terdapat wifi dan hotspot area yang tersedia di beberapa titik sekolah. Hal ini dimaksudkan agar siswa dapat mencari materi pembelajaran dari internet untuk menunjang prestasi belajarnya. Guru mendukung pemanfaatan internet yang dilakukan siswa untuk kepentingan pembelajaran dengan tetap memberikan arahan dan bimbingan agar dapat memanfaatkan internet secara bijak dan tidak memanfaatkan internet untuk hal yang tidak berkaitan dengan pembelajaran. Namun pada kenyataannya, masih ada siswa yang kurang sesuai dalam memanfaatkan internet yaitu membuka situs pertemanan jejaring sosial dan bermain game online pada saat jam pembelajaran berlangsung sehingga akan menghambat proses belajar dan akan berimbas pada pencapaian prestasi belajar.

Mengacu pemaparan di atas, terdapat hasil penelitian-penelitian terdahulu yang berbeda dan ada masalah dari variabel manajemen kelas, kesiapan belajar dan pemanfaatan internet yang diindikasi akan mempengaruhi prestasi belajar. Berdasarkan hal itu, peneliti tertarik untuk melakukan penelitian akan topik prestasi belajar dengan mengkaji beragam variabel yang masih diperlukan penelitian yakni variabel manajemen kelas, kesiapan belajar dan pemanfaatan internet.

\section{Tujuan Penelitian}


Tujuan umum dalam peneitian ini yaitu untuk menguji pengaruh manajemen kelas, kesiapan belajar dan pemanfaatan internetterhadap prestasi belajar ekonomi siswa kelas X IPS SMA Negeri 4 Purwokerto. Sementara itu, tujuan khusus dalam penelitian yaitu: (1) Untuk menganalisis pengaruh positif manajemen kelas terhadap prestasi belajar ekonomi siswa kelas X IPS SMA Negeri 4 Purwokerto. (2) Untuk menganalisis pengaruh positif kesiapan belajar terhadap prestasi belajar ekonomi siswa kelas X IPS SMA Negeri 4 Purwokerto. (3) Untuk menganalisis pengaruh positif pemanfaatan internet terhadap prestasi belajar ekonomi siswa kelas X IPS SMA Negeri 4 Purwokerto. (4) Untuk menganalisis pengaruh manajemen kelas, kesiapan belajar dan pemanfaatan internet secara simultan terhadap prestasi belajar ekonomi siswa kelas X IPS SMA Negeri 4 Purwokerto.

\section{Ruang Lingkup Penelitian}

Ruang lingkup penelitian ini yaitu manajemen kelas yang diukur dibatasi pada manajemen kelas yang dilakukan oleh guru saat pembelajaran materi ekonomi, kesiapan belajar siswa begitu mengikuti pembelajaran materi ekonomi dan pemanfaatan internet yang diukur dalam penelitian ini yaitu pemanfaatan internet dalam pembelajaran ekonomi, serta prestasi belajar ekonomi memanfaatkan nilai rapor semester gasal kelas X IPS SMA Negeri 4 Purwokerto tahun ajaran $2018 / 2019$.

\section{TINJAUAN PUSTAKA DAN PERUMUSAN HIPOTESIS}

\section{Prestasi Belajar}

Menurut Sukmadinata (2009:102-103) prestasi belajar (achievement) yakni pemekaran/realisasi dari potensi yang terdapat di dalam diri seseorang dan direpresentasikan melalui huruf maupun angka. Selain itu, prestasi belajar juga didefinisikan sebagai kompetensi dalam hal pengetahuan yang ditingkatkan melalui mata pelajaran dan umumnya dibuktikan menggunakan nilai yang diberikan guru (Kamus Besar Bahasa Indonesia, 2008:1101). Slameto (2010:54-72) menyatakan bahwa faktor-faktor yang mempengaruhi prestasi belajar yaitu faktor intern dan faktor ekstern. Faktor intern merupakan komponen yang sumbernya berasal dari peserta didik yang mempengaruhi kemampuan dalam belajarnya mencakup jasmaniah terdiri dari kesehatan dan cacat tubuh, psikologis meliputi inteligensi, perhatian, minat, bakat, kematangan, kesiapan serta motif dan kelelahan yang terdiri dari kelelahan jasmani serta kelelahan rohani. Sementara itu, faktor ekstern adalah komponen yang sumbernya dari luar diri peserta didik yang mempengaruhi prestasi belajar yaitu keluarga (cara orang tua mendidik, hubungan antar anggota keluarga, suasana tempat tinggal, kondisi ekonomi keluarga, latar 
belakang kebudayaan serta pengertian orang tua), masyarakat (mass media, teman sebaya, aktivitas siswa dalam masyarakat serta bentuk kehidupan masyarakat) dan sekolah (kurikulum, metode mengajar, disiplin sekolah, hubungan guru dengan siswa, alat pelajaran, hubungan antar siswa, waktu sekolah, keadaan gedung, metode belajar, standar pelajaran di atas ukuran dan tugas rumah). Indikator dari prestasi belajar yaitu portofolio prestasi belajar rata-rata siswa dalam bentuk nilai rapor mata pelajaran ekonomi semester gasal tahun ajaran 2018/2019.

\section{Manajemen Kelas}

Menurut Tim Dosen Administrasi Pendidikan Universitas Pendidikan Indonesia (2011:106) manajemen kelas adalah keseluruhan upaya guna menciptakan suasana pembelajaran yang kondusif serta memotivasi siswa agar belajar dengan baik selaras dengan potensi yang dimilikinya. Menurut Karwati dan Priansa (2014:6) manajemen kelas diartikan sebagai sebuah proses dalam melakukan perencanaan, pengorganisasian, pengaktualisasian serta melaksanakan pengendalian atas aktivitas yang terdapat di dalam kelas yang membuat proses pembelajaran berlangsung efektif dan mengoptimalkan kemampuan siswa.Indikator manajemen kelas terdiri dari lingkungan fisik, kondisi sosio-emosional dan kondisi organisasional (Tim Dosen Administrasi PendidikanUniversitas Pendidikan Indonesia, 2009:112-114).

\section{Kesiapan Belajar}

Kesiapan ialah keadaan individu yang mempersiapkan diri untuk menyampaikan tanggapan dengan gaya tertentu pada situasi yang dihadapi (Slameto, 2010:113). Menurut Ibrahim dan Sukmadinata (2010:74) kesiapan merupakan keadaan siap untuk memberikan respon baik mental maupun fisik agar melaksanakan tindakan. Kegiatan pembelajaran tidak dapat berjalan dengan lancar, jika dilakukan tanpa adanya kesiapan belajar. Kondisi kesiapan belajar ini harus dapat dimiliki oleh siswa. Siswa harus mempersiapkan kondisi kesiapan belajar yang baik agar mudah dalam mengikuti proses pembelajaran serta memperoleh hasil belajar yang baik. Indikator kesiapan belajar terdiri dari kondisi fisik dan kondisi mental, kondisi emosional, kebutuhan, motif dan tujuan serta keterampilan dan pengetahuan(Slameto, 2010:113).

\section{Pemanfaatan Internet}

Menurut Sanjaya (2012:216) internet adalah sistem yang menghubungkan jaringan komputer menjadi satu kesatuan. Rusman (2013:343) mengemukakan bahwa internet ialah sebuah jaringan global berupa gabungan dari jaringan komputer di seluruh dunia. Internet dapat 
memudahkan pengguna memperoleh pengetahuan dari berbagai penyedia informasi melalui komunikasi protokol yang disebut Transmission Control Protocol (TCP). Pemanfaatan menurut Kamus Besar Bahasa Indonesia (2008:873) mengandung arti "proses, cara dan perbuatan memanfaatkan". Sehingga pemanfaaatan internet dapat diartikan sebagai proses memanfaatkan internet untuk memperoleh informasi. Riyanto (2012) menyatakan bahwa pemanfaatan internet yaitu pengambilan informasi, melakukan komunikasi dengan pihak lain serta meringankan siswa ketika mengerjakan tugas. Pemanfaatan internet akan mendukung peserta didik untuk menambah waktu dan mutu dalam belajar. Hal ini akan meningkatkan kualitas pembelajaran yang diperoleh. Indikator pemanfaatan internet terdiri dari intesitas waktu penggunaan internet, jenis layanan internet serta fungsi menggunakan internet (Putra, 2017).

\section{Perumusan Hipotesis}

\section{Pengaruh Manajemen Kelas Terhadap Prestasi Belajar}

Menurut Tim Dosen Administrasi Pendidikan (2011:106) manajemen kelas adalah keseluruhan upaya guna menciptakan suasana pembelajaran yang kondusif serta memotivasi siswa agar belajar dengan baik selaras dengan potensi yang dimilikinya. Tujuan pengajaran akan tercapai apabila kondisi belajar tetap kondusif sehingga prestasi belajar menjadi bertambah baik. Berdasarkan hal tersebut, manajemen kelas mempunyai pengaruh yang positif terhadap prestasi belajar.

Penelitian Khofifah (2016) membuktikan manajemen kelas mempunyai pengaruh positif terhadap prestasi belajar. Selaras penelitian Omenka dan Otor (2015) menunjukkan manajemen kelas secara signifikan mempengaruhi prestasi akademik siswa. Lain halnya penelitian Supriyati (2015) yang hasilnya menyebutkan tidak ada pengaruh signifikan antara manajemen atau kemampuan pengelolaan kelas terhadap prestasi belajar, manajemen kelas hanya mempengaruhi aktivitas pembelajaran.

Berdasarkan penjelasan teori dan terdapat hasil penelitian yang berlainan, peneliti ingin meneliti secara langsung dengan rumusan hipotesis:

$\mathrm{H}_{1}$ : manajemen kelas berpengaruh positif terhadap prestasi belajar

\section{Pengaruh Kesiapan Belajar Terhadap Prestasi Belajar}

Slameto (2013:113) kesiapan merupakan segala keadaan individu yang mempersiapkan diri untuk memberikan tanggapan dengan gaya tertentu terhadap suatu situasi. Kesiapan ini merupakan pendahuluan dalam melakukan kegiatan belajar atau terjadi ketika kegiatan belajar 
belum berlangsung. Seseorang yang sudah siap untuk melakukan kegiatan belajar, berada dalam kondisi sanggup melaksanakan semua aktivitas yang hendak dilakukan.Slameto (2010:59) menyatakan bahwa kesiapan belajar berpengaruh terhadap prestasi belajar, dimana peserta didik yang mempunyai kesiapan, maka prestasi belajarnya jelas lebih baik.

Hasil penelitian Bujuri (2015) menunjukkan ada pengaruh yang positif dan signifikan kesiapan belajar terhadap prestasi belajar. Berbeda dengan penelitian Hotimah (2012) yang menyatakan bahwa tidak ada pengaruh kesiapan belajar terhadap prestasi belajar.

Berdasarkan penjelasan teori dan terdapat hasil penelitian yang berlawanan, peneliti ingin mengkaji langsung dengan rumusan hipotesis:

\section{$\mathrm{H}_{2}$ : kesiapan belajar berpengaruh positif terhadap prestasi belajar}

\section{Pengaruh Pemanfaatan Internet Terhadap Prestasi Belajar}

Menurut Sanjaya (2012:216) internet adalah sistem yang menghubungkan jaringan komputer menjadi satu kesatuan. Pemanfaatan internet merupakan salah satu sumber untuk memperoleh informasi mengenai penjelasan materi pelajaran yang lebih mendetail. Siswa yang dapat memanfaatkan internet untuk menunjang kegiatan belajar, maka hasil dari kegiatan tersebut adalah prestasi belajar yang baik. Senada dengan pendapat yang dikemukakan oleh Rusman (2013:344) memakai internet dengan berbagai jenis layanan yang ditawarkan dapat melancarkan dalam hal perolehan informasi dalam dunia edukasi sehingga menambah pengetahuan siswa.

Menurut Utami (2012) pemanfaatan internet memiliki pengaruh yang positif terhadap prestasi belajar. Senada dengan Shahibi dan Rusli (2017) penggunaan internet atau media online untuk pendidikan membantu siswa dalam meningkatkan prestasi akademik. Berbeda dengan Samiaji(2009) penelitiannya menjelaskan bahwa tidak ada pengaruh pemanfaatan internet terhadap prestasi belajar.

Berdasarkan penjelasan teori dan terdapat hasil penelitian yang berlainan, peneliti ingin meneliti langsung dengan rumusan hipotesis:

$\mathrm{H}_{3}$ : pemanfaatan internet berpengaruh positif terhadap prestasi belajar

\section{Pengaruh Manajemen Kelas, Kesiapan Belajar dan Pemanfaatan Internet Secara Simultan Terhadap Prestasi Belajar}

Slameto (2010:54-72) mengemukakan prestasi belajar dipengaruhi beberapa faktor yang bersumber dari pribadi siswa (intern) maupun dari luar pribadi siswa (ekstern). Faktor ekstern meliputi keluarga, faktor masyarakat diantaranya mass media berupa internet dan sekolah (kurikulum, metode mengajar, disiplin sekolah, hubungan guru dengan siswa, alat pelajaran, 
hubungan antar siswa, waktu sekolah, kondisi bangunan, cara belajar, standar pelajaran di atas ukuran dan tugas rumah). Pengaturan metode, strategi serta kelengkapan dalam pengajaran merupakan bagian dari kegiatan manajemen kelas (Tim dosen administrasi pendidikan, 2011:103).Sementara itu, faktor intern memuat jasmaniah, kelelahan dan psikologis. Salah satu faktor psikologis yang mempengaruhi prestasi belajar adalah kesiapan.

Menurut Khofifah (2016) manajemen kelas berpengaruh positif terhadap prestasi belajar siswa. Bujuri (2015) dalam penelitiannya ada pengaruh yang positif dan signifikan kesiapan belajar terhadap prestasi belajar. Penelitian yang dilakukan oleh Utami (2012) menunjukkan bahwa pemanfaatan internet berpengaruh positif terhadap prestasi belajar siswa. Sehingga dapat disimpulkan manajemen kelas, kesiapan belajar dan pemanfaatan internet dapat berpengaruh secara simultan terhadap prestasi belajar dan rumusan hipotesisnya sebagai berikut:

\section{$\mathbf{H}_{4}$ : manajemen kelas, kesiapan belajar dan pemanfaatan internet berpengaruh secara simultan terhadap prestasi belajar}

\section{Kerangka Berfikir}

Menurut Sukmadinata (2009:102-103) prestasi belajar (achievement) yakni pemekaran/realisasi dari potensi yang terdapat di dalam diri seseorang dan direpresentasikan melalui huruf maupun angka. Slameto (2010:54-72) menyatakan faktor-faktor yang mempengaruhi prestasi belajar yaitu ekstern dan intern. Faktor ekstern (bersumber dari luar) salah satunya yakni manajemen kelas. Menurut Tim Dosen Administrasi Pendidikan (2011:106) manajemen kelas ialah keseluruhan upaya untuk menciptakan atmosfer pembelajaran yang tepat dan mengasyikan juga siswa diberikan motivasi untuk belajar dengan baik selaras dengan keterampilan yang dimilikinya. Penelitian Khofifah (2016) membuktikan manajemen kelas mempunyai pengaruh positif terhadap prestasi belajar.

Faktor intern (bersumber dari dalam diri) salah satunya ialah kesiapan belajar. Ibrahim dan Syaodih (2010:74) mengemukakan bahwa kesiapan merupakan keadaan siap untuk memberikan respon baik mental maupun fisik untuk melakukan suatu kegiatan. Menurut Slameto (2010:59) kesiapan belajar berpengaruh terhadap prestasi belajar, dimana siswa dengan kesiapan belajar yang baik, maka prestasi belajarnya jelas lebih baik. Hal ini diperkuat oleh Bujuri (2015) dalam penelitiannya ada pengaruh positif dan signifikan kesiapan belajar terhadap prestasi belajar.

Menurut Sanjaya (2012:216) internet adalah sistem yang menghubungkan jaringan komputer menjadi satu kesatuan. Pemanfaatan internet akan membantu siswa meningkatkan kuantitas dan kualitas dalam belajar. Penelitian Utami (2012) membuktikan bahwa pemanfaatan internet berpengaruh positif terhadap prestasi belajar. 
Mengacu pada telaah pustaka dan pengembangan hipotesis serta penelitian terdahulu, dapat dirumuskan sebuah kerangka berfikir berikut :

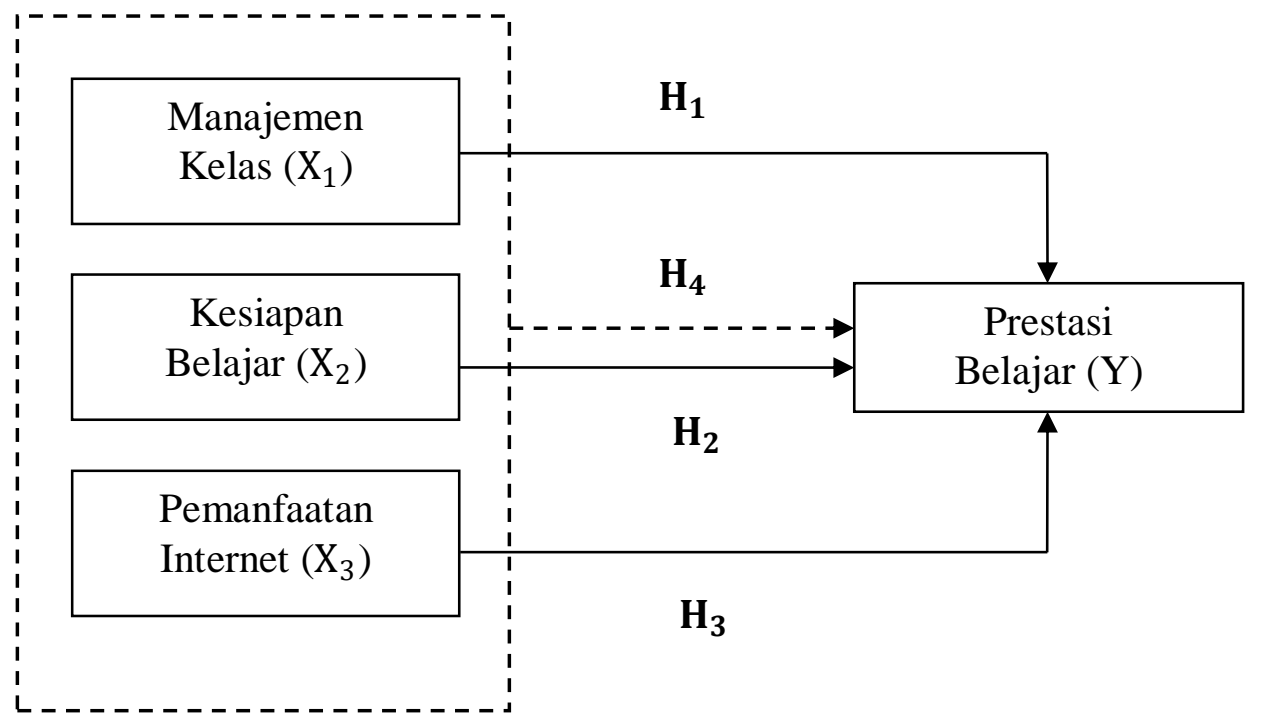

\section{Gambar 1. Kerangka Berfikir}

Keterangan :

$\mathrm{X}_{1} \quad$ : Manajemen Kelas

$\mathrm{X}_{2}$ : Kesiapan Belajar

$\mathrm{X}_{3} \quad$ : Pemanfaatan Internet

Y : Prestasi Belajar

$\longrightarrow$ : Pengaruh manajemen kelas, kesiapan belajar dan pemanfaatan Internet secara parsial terhadap prestasi belajar

_. $\rightarrow$ : Pengaruh manajemen kelas, kesiapan belajar dan pemanfaatan internet secara simultan terhadap prestasi belajar

\section{METODE PENELITIAN}

Penelitian yang dilaksanakan tergolong jenis deskriptif dengan teknik kuantitatif yakni penelitian yang memaparkan suatu keadaan saat ini beserta data yang ditunjukkan dengan mengambil data melalui angket dan melakukan analisis statistik.

Populasi yang ditentukkan yaitu siswa kelas X IPS di SMA Negeri 4 Purwokerto tahun ajaran 2018/2019 yang berjumlah 141 siswa. Sampel dengan tipe simple random dengan jumlah sampel sebesar 105 siswa yang dihitung berdasarkan rumus Slovin diperoleh jumlah sampel tiap kelas yaitu kelas X IPS 1 berjumlah 27 siswa, X IPS 2 berjumlah 26 siswa, X IPS 3 berjumlah 27 siswa dan X IPS 4 berjumlah 25 siswa.

Jenis data yang digunakan yaitu data primer dan data sekunder. Dalammemperoleh data untuk penelitian ini penulis menggunakan teknik kuesioner dan dokumentasi, yang digunakan untuk mendapatkan informasi terkait variabel yang digunakan yakni manajemen kelas, kesiapan 
belajar dan pemanfaatan internet. Uji instrumen terdiri dari uji instrumen kuesioner. Instrumen diuji coba untuk mengetahui validitas, reliabilitas, dengan menggunakan skala likert 1-4.

Sebelum dilakukan uji analisis data, maka data penelitian harus dilakukan uji asumsi klasik terlebih dahulu meliputi uji normalitas, uji multikolinieritas danujiheteroskedastistas. Analisis data menggunakan analisisberikutini

(1) Analisis regresi linier berganda

Suliyanto (2011:54) menyatakan bahwa regresi linier berganda merupakan analisis ketergantungan dari dua atau lebih variabel bebas terhadap satu variabel tergantung. Rumus yang digunakan untuk tiga predictor adalah sebagai berikut :

Keterangan :

$$
Y=\alpha+b_{1} X_{1}+b_{2} X_{2}+b_{3} X_{3}+\varepsilon
$$

Y : variabel prestasi belajar ekonomi

$b_{1}$ : koefisien regresi manajemen kelas

$X_{1}$ : manajemen kelas

$b_{2}:$ koefisien kesiapan belajar

$X_{2}$ : kesiapan belajar

$b_{3}$ : koefisien pemanfaatan internet

$X_{3}$ : pemanfaatan internet

$\varepsilon$ : nilai residu

(2) Ujikoefisiendeterminasi

Untuk melihat pemberian andil dari variabel bebas atas variabel terikatnya dapat melalui koefisien determinasi $\left(R^{2}\right)$. Dalam model regresi linear berganda diperlukan perhitungan $R^{2}$ yang telah disesuaikan, Adjusted $R$ Square $\left(R_{a d j}^{2}\right)$. Hal ini mempunyai arti telah terjadi penyempuarnaan yang mengikutsertakan keseluruhan variabel serta sampel dalam model (Suliyanto, 2011:43). untuk menghitung besarnya kedua teknik ini yaitu :

Teknik koefisien determinasi :

Keterangan :

$$
R^{2}=1-\frac{\sum(Y-\hat{Y})^{2}}{\sum(Y-\bar{Y})^{2}}
$$

$R^{2} \quad$ : koefisien determinasi

$(Y-\hat{Y})^{2} \quad$ : kuadrat selisih nilai Y riil dengan nilai Y prediksi

$(Y-\bar{Y})^{2} \quad$ : kuadrat selisih nilai Y riil dengan nilai Y rata-rata

Teknik Adjusted R Square :

Keterangan :

$$
R_{a d j}^{2}=R^{2}-\frac{P\left(1-R^{2}\right)}{N-P-1}
$$

$R^{2}$ : koefisien determinasi

$\mathrm{N}$ : banyaknya sampel

P : jumlah variabel bebas

(3) Uji F

Menurut Suliyanto (2011:655) untuk mengetahui pengaruh variabel bebas secara simultan terhadap variabel terikat digunakan perhitungan uji F. Apabila terdeteksi berpengaruh 
secara simultan, dapat dikatakan model tergolong kategori fit dan berlaku juga untuk sebaliknya. Perhitungan uji F ini dapat dicari menggunakan rumus sebagai berikut :

Keterangan :

$$
F=\frac{R^{2} /(k-1)}{\left(1-R^{2}\right) /(n-k)}
$$

$\mathrm{F}$ : nilai F hitung

$R^{2}:$ koefisien determinasi

$k$ : jumlah variabel

$n$ : jumlah pengamatan (ukuran sampel)

1) Kriteria Penerimaan dan Penolakan Hipotesis

$$
H_{0}: \beta_{1}=\beta_{2}=\beta_{3}=0
$$

Tidak ada pengaruh manajemen kelas, kesiapan belajar dan pemanfaatan internet secara simultan terhadap prestasi belajar.

$H_{a}: \beta_{1} \neq \beta_{2} \neq \beta_{3} \neq 0$

Terdapat pengaruh manajemen kelas, kesiapan belajar dan pemanfaatan internet secara simultan terhadap prestasi belajar.

2) Kriteria signifikansi yakni $5 \%$

3) Kiteria pengujian :

Nilai $F_{\text {hitung }}<F_{\text {tabel }}$ atau nilai Sig. $>0,05$ maknanya model tidak memiliki kategori yang fit

Nilai $F_{\text {hitung }}>F_{\text {tabel }}$ atau nilai Sig. $<0,05$ maknanya model memiliki kategori yang fit

(4) Uji t

Uji $t$ berguna menguji apakah variabel bebas berpengaruh signifikan atas variabel tergantung (Suliyanto, 2011: 62). Pada bagian ini dapat menggunakan persamaan berikut :

$$
t_{i}=\frac{b j}{S b j}
$$

Keterangan :

t : nilai t hitung

bj : koefisien regresi

Sbj : kesalahan baku koefisien regresi

1) Kriteria Penerimaan dan Penolakan Hipotesis Pertama

$H_{0}: \beta_{1}=0$ : Manajemen kelas tidak berpengaruh positif terhadap prestasi belajar.

$H_{a}: \beta_{1}>0$ : Manajemen kelas berpengaruh positif terhadap prestasi belajar.

Kriteria signifikansi yakni 5\%

Kriteria pengujian :

$t_{\text {hitung }} \leq t_{\text {tabel }}$ atau Sig $>5 \%=$ maknanya $H_{o}$ diterima

$t_{\text {hitung }}>t_{\text {tabel }}$ atau Sig $\leq 5 \%=$ maknanya $H_{a}$ diterima

2) Kriteria Penerimaan dan Penolakan Hipotesis Kedua

$H_{0}: \beta_{2}=0:$ Kesiapan belajar tidak berpengaruh positif terhadap prestasi belajar.

$H_{a}: \beta_{2}>0:$ Kesiapan belajar berpengaruh positif terhadap prestasi belajar.

Kriteria signifikansi yakni 5\%

Kriteria pengujian :

$t_{\text {hitung }} \leq t_{\text {tabel }}$ atau Sig $>5 \%=$ maknanya $H_{o}$ diterima

$t_{\text {hitung }}>t_{\text {tabel }}$ atau Sig $\leq 5 \%=$ maknanya $H_{a}$ diterima

3) Kriteria Penerimaan dan Penolakan Hipotesis Ketiga 


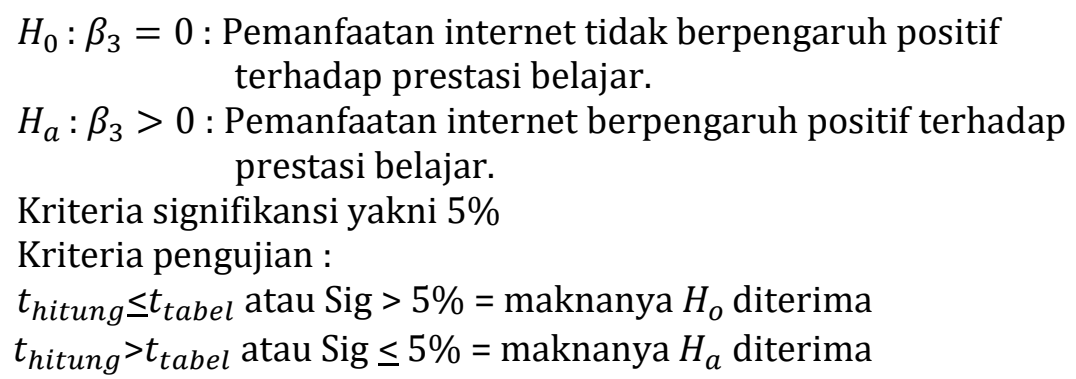

(5) Uji Elastisitas

Uji elastisitas digunakan untuk mengetahui variabel bebas yang paling berpengaruh terhadap variabel terikat. Perhitungan uji elastisitas atau uji koefisien beta ini dapat digunakan menggunakan rumus sebagai berikut :

$$
\begin{aligned}
& \varepsilon=\beta i \frac{\overline{x_{i}}}{\bar{Y}} \\
& \text { Keterangan : } \\
& \varepsilon: \text { nilai elastisitas sebuah variabel } \\
& \beta i: \text { koefisien regresi } \\
& \overline{x_{i}}: \text { rata-rata variabel bebas } \\
& \bar{Y}: \text { rata-rata variabel terikat }
\end{aligned}
$$

\section{HASIL DAN PEMBAHASAN}

Penelitian ini menganalisis pengaruh manajemen kelas, kesiapan belajar dan pemanfaatan internet terhadap prestasi belajar. Angket diserahkan pada responden dengan total 105 siswa. Terdiri dari dua pernyataan yaitu pernyataan positif dan pernyataan negatif. Untuk pernyataan positif diukur dengan skala 1 sampai 4 . Skala 1 mencerminkan sangat tidak setuju, skala 2 mencerminkan tidak setuju, skala 3 mencerminkan setuju dan skala 4 mencerminkan sangat setuju. Sementara itu, pernyataan negatif diukur dengan skala 1 mencerminkan sangat setuju, skala 2 mencerminkan setuju, skala 3 mencerminkan tidak setuju dan skala 4 mencerminkan sangat tidak setuju.

Manajemen kelas terdiri dari 3 indikator dan penjabaran pernyataan hingga 13 butir. Jawaban responden dari manajemen kelas tercatat di tabel 10 berikut:

Tabel 10. Jawaban Responden Manajemen Kelas Pernyataan Positif

\begin{tabular}{llcccc}
\hline No & \multicolumn{1}{c}{$\begin{array}{c}\text { Jawaban } \\
(1)\end{array}$} & $\begin{array}{c}\text { Skor } \\
(2)\end{array}$ & $\begin{array}{c}\text { Frekuensi } \\
(3)\end{array}$ & $\begin{array}{c}\text { Jumlah } \\
(2) \times(3)\end{array}$ & $\begin{array}{c}\text { Presentase } \\
(\%)\end{array}$ \\
\hline 1 & $\begin{array}{l}\text { Sangat Tidak } \\
\text { Setuju }\end{array}$ & 1 & 3 & 3 & 0,08 \\
& & & & \\
2 & Tidak Setuju & 2 & 48 & 96 & 2,48 \\
3 & Setuju & 3 & 649 & 1947 & 50,36
\end{tabular}




\begin{tabular}{|c|c|c|c|c|}
\hline 4 & Sangat Setuju & 455 & 1820 & 47,08 \\
\hline & Total & 1155 & 3866 & 100 \\
\hline & Rata-rata Jawaban & 3,35 & & \\
\hline
\end{tabular}

Responden paling banyak memilih jawaban setuju dengan 50,36\% dan paling sedikit memilih jawaban sangat tidak setuju dengan 0,08\%. Rata-rata jawaban responden sebesar 3,35. Angka tersebut menunjukkan bahwa jawaban responden termasuk dalam kriteria setuju. Kesimpulannya manajemen kelas yang dilakukan guru ekonomi tergolong baik karena sebagian besar responden memilih jawaban setuju.

Tabel 11. Jawaban Responden Manajemen Kelas Pernyataan Negatif

\begin{tabular}{llcccc}
\hline No & \multicolumn{1}{c}{$\begin{array}{c}\text { Jawaban } \\
(1)\end{array}$} & $\begin{array}{c}\text { Skor } \\
(2)\end{array}$ & $\begin{array}{c}\text { Frekuensi } \\
(3)\end{array}$ & $\begin{array}{c}\text { Jumlah } \\
(2) \times(3)\end{array}$ & $\begin{array}{c}\text { Presentase } \\
(\%)\end{array}$ \\
\hline 1 & Sangat Tidak & 4 & 85 & 340 & 48,23 \\
& Setuju & & & & \\
2 & Tidak Setuju & 3 & 117 & 351 & 49,79 \\
3 & Setuju & 2 & 6 & 12 & 1,70 \\
4 & Sangat Setuju & 1 & 2 & 2 & 0,28 \\
\hline & Total & 210 & 705 & 100 \\
\hline & Rata-rata Jawaban & 3,36 & & \\
\hline
\end{tabular}

Tabel 11 menunjukkan bahwa responden paling banyak memilih jawaban tidak setuju dengan $49,79 \%$ dan paling sedikit memilih jawaban sangat setuju dengan 0,28\%. Rata-rata jawaban responden sebesar 3,36. Angka tersebut menunjukkan bahwa jawaban responden termasuk dalam kriteria tidak setuju. Kesimpulannya manajemen kelas yang dilakukan guru ekonomi tergolong baik karena sebagian besar responden memilih jawaban tidak setuju.

Variabel kesiapan belajar mencakup 4 indikator dan penjabaran hingga 15 pernyataan. Jawaban responden tercatat di tabel 12 berikut:

Tabel 12. Jawaban Responden Kesiapan Belajar Pernyataan Positif

\begin{tabular}{llcccc}
\hline No & \multicolumn{1}{c}{$\begin{array}{c}\text { Jawaban } \\
(1)\end{array}$} & $\begin{array}{c}\text { Skor } \\
(2)\end{array}$ & $\begin{array}{c}\text { Frekuensi } \\
(3)\end{array}$ & $\begin{array}{c}\text { Jumlah } \\
(2) \times(3)\end{array}$ & $\begin{array}{c}\text { Presentase } \\
(\%)\end{array}$ \\
\hline 1 & Sangat Tidak & 1 & 16 & 16 & 0,43 \\
& Setuju & & & & \\
2 & Tidak Setuju & 2 & 108 & 216 & 5,79 \\
3 & Setuju & 3 & 624 & 1872 & 50,16 \\
4 & Sangat Setuju & 4 & 407 & 1628 & 43,62 \\
\hline & Total & 1155 & 3732 & 100 \\
\hline & Rata-rata Jawaban & 3,23 & & \\
\hline
\end{tabular}

Pada tabel 12 responden paling banyak memilih jawaban setuju dengan 50,16\% dan paling sedikit memilih jawaban sangat tidak setuju dengan 0,43\%. Rata-rata jawaban responden sebesar 3,23. termasuk dalam kriteria jawaban setuju. Dengan demikian, kesiapan belajar responden tergolong baik karena sebagian besar responden memilih jawaban setuju.

Tabel 13. Jawaban Responden Kesiapan Belajar Pernyataan Negatif

\begin{tabular}{cccccc}
\hline No & \multicolumn{1}{c}{ Jawaban } \\
& \multicolumn{1}{c}{$(1)$} & $\begin{array}{c}\text { Skor } \\
(2)\end{array}$ & $\begin{array}{c}\text { Frekuensi } \\
(3)\end{array}$ & $\begin{array}{c}\text { Jumlah } \\
(2) \times(3)\end{array}$ & $\begin{array}{c}\text { Presentase } \\
(\%)\end{array}$ \\
\hline 1 & $\begin{array}{l}\text { Sangat Tidak } \\
\text { Setuju }\end{array}$ & 4 & 155 & 620 & 45,32
\end{tabular}




\begin{tabular}{llcccc}
2 & Tidak Setuju & 3 & 223 & 669 & 48,90 \\
3 & Setuju & 2 & 37 & 74 & 5,41 \\
4 & Sangat Setuju & 1 & 5 & 5 & 0,37 \\
\hline & Total & 420 & 1368 & 100 \\
\hline & Rata-rata Jawaban & 3,26 & & \\
\hline
\end{tabular}

Tabel 13 menunjukkan bahwa responden paling banyak memilih jawaban tidak setuju dengan $48,90 \%$ dan paling sedikit memilih jawaban sangat setuju dengan $0,37 \%$. Rata-rata jawaban responden sebesar 3,26 yang termasuk dalam kriteria jawaban tidak setuju. Jadi kesimpulannya adalah kesiapan belajar responden tergolong baik karena sebagian besar responden memilih jawaban tidak setuju pada pernyataan negatif.

Variabel pemanfaatan internet berisi 3 indikator dan penjabaran hingga 13 pernyataan. Jawaban dari pemanfaatan internet termuat pada tabel 14 berikut:

\begin{tabular}{|c|c|c|c|c|c|}
\hline No & $\begin{array}{l}\text { Jawaban } \\
\text { (1) }\end{array}$ & $\begin{array}{l}\text { Skor } \\
(2)\end{array}$ & $\begin{array}{l}\text { Frekuensi } \\
\text { (3) }\end{array}$ & $\begin{array}{l}\text { Jumlah } \\
(2) \times(3)\end{array}$ & $\begin{array}{c}\text { Presentase } \\
(\%)\end{array}$ \\
\hline 1 & $\begin{array}{ll}\text { Sangat } & \text { Tidak } \\
\text { Setuju } & \end{array}$ & 1 & 3 & 3 & 0,08 \\
\hline 2 & Tidak Setuju & 2 & 45 & 90 & 2,53 \\
\hline 3 & Setuju & 3 & 552 & 1656 & 46,61 \\
\hline \multirow[t]{2}{*}{4} & Sangat Setuju & 4 & 451 & 1804 & 50,77 \\
\hline & Total & & 1051 & 3553 & 100 \\
\hline
\end{tabular}

Tabel 14 memaparkan informasi bahwa responden paling banyak memilih jawaban sangat setuju dengan $50,77 \%$ dan paling sedikit memilih jawaban sangat tidak setuju dengan 0,08\%. Rata-rata jawaban responden sebesar 3,38 yang termasuk dalam kriteria jawaban setuju. Jadi kesimpulan yang dapat diambil yaitu pemanfaatan internet responden tergolong baik karena mayoritas responden memilih jawaban setuju.

\begin{tabular}{clcccc}
\multicolumn{6}{c}{ Tabel 15. Jawaban Responden Pemanfaatan Internet Pernyataan Negatif } \\
\hline No & \multicolumn{1}{c}{$\begin{array}{c}\text { Jawaban } \\
(1)\end{array}$} & $\begin{array}{c}\text { Skor } \\
(2)\end{array}$ & $\begin{array}{c}\text { Frekuensi } \\
(3)\end{array}$ & $\begin{array}{c}\text { Jumlah } \\
(2) \times(3)\end{array}$ & $\begin{array}{c}\text { Presentase } \\
(\%)\end{array}$ \\
\hline 1 & $\begin{array}{l}\text { Sangat } \\
\text { Tidak }\end{array}$ & 4 & 127 & 508 & 49,42 \\
& Setuju & & & & \\
2 & Tidak Setuju & 3 & 166 & 498 & 48,44 \\
3 & Setuju & 2 & 17 & 17 & 1,65 \\
4 & Sangat Setuju & 1 & 5 & 5 & 0,49 \\
\hline & Total & 315 & 1028 & 100 \\
\hline
\end{tabular}

Tabel 15 dapat diketahui bahwa responden paling banyak memilih jawaban sangat tidak setuju dengan $49,42 \%$ dan paling sedikit memilih jawaban sangat setuju dengan 0,49\%. Rata-rata jawaban responden sebesar 3,26 yang termasuk dalam kriteria jawaban tidak setuju. Sehingga kesimpulan yang dapat diambil yaitu pemanfaatan internet responden tergolong baik karena mayoritas jawaban responden memilih jawaban tidak setuju.

Data sekunder yang didapatkan dari sekolah yaitu dari nilai rapor ekonomi semester gasal tahun ajaran 2018/2019 dapat dijelaskan pada tabel 8. Besarnya nilai Kriteria Ketuntasan 
Minimal adalah 75. Distribusi frekuensi responden berdasarkan prestasi belajar tercantum di tabel 8.

Tabel 8. Kategori Frekuensi Prestasi Belajar Ekonomi Berdasarkan KKM

\begin{tabular}{ccccc}
\hline No & Interval Nilai & Frekuensi & Persentase (\%) & Kategori \\
\hline 1 & $0-74,99$ & 0 & 0 & Tidak Tuntas \\
2 & $75-100$ & 105 & 100 & Tuntas \\
\hline & Total & 105 & 100 & \\
\hline
\end{tabular}

Sumber: Datftar nilai rapor mata pelajaran ekonomi siswa kelas X IPS SMA Negeri 4 Purwokerto tahun ajaran 2018/2019.

Tabel 8 memamparkan informasi bahwa keseluruhan prestasi belajar ekonomi siswa mencapai kriteria tuntas. Penggolongan ini dibagi menjadi empat kategori yang tercantum di tabel 9.

Tabel 9. Kategori Frekuensi Prestasi Belajar Ekonomi

\begin{tabular}{cccccc}
\hline No & $\begin{array}{c}\text { Kelas } \\
\text { Interval }\end{array}$ & $\begin{array}{c}\text { Nilai } \\
\text { Huruf }\end{array}$ & Frekuensi & $\begin{array}{c}\text { Presentase } \\
(\%)\end{array}$ & Kategori \\
\hline 1 & $93-100$ & A & 0 & 0 & Sangat Baik \\
2 & $84-92,99$ & B & 74 & 70,48 & Baik \\
3 & $75-83,99$ & C & 31 & 29,52 & Cukup \\
4 & $0-74,99$ & D & 0 & 0 & Kurang \\
\hline \multicolumn{7}{c}{ Total } & & 105 & 100 & \\
\hline
\end{tabular}

Mengacu penggolongan kategori prestasi belajar ekonomi di atas dapat diketahui bahwa prestasi belajar ekonomi siswa kelas X IPS SMA Negeri 4 Purwokerto termasuk dalam kategori baik yaitu sebesar 74 atau $70,48 \%$.

Selanjutnya dilakukan pengujian normalitas, multikolinearitas, danheteroskedastisitas. Hasil perhitungan normalitas pada tabel di atas diketahui angka signifikansi 0,200 >0,05 sehingga diambil kesimpulan nilai residual memiliki distribusi yang normal. Berdasarkan perhitungan multikolinieritas nilai tolerance variabel manajemen kelas yaitu 0,746 $>0,10$, kesiapan belajar sebesar 0,812 $>0,10$ dan pemanfaatan internet sebesar 0,898 > 0,10 serta nilai VIF dari variabel manajemen kelas sebesar 1,340 < 10, variabel kesiapan belajar sebesar 1,232 $<10$ dan variabel pemanfaatan internet sebesar 1,114 < 10 kesimpulannya tidak ada unsur multikolineritas diantara variabel bebas. Hasil uji heteroskedastisitas diperoleh nilai Sig. variabel manajemen kelas sebesar 0,130 >0,05, variabel kesiapan belajar bernilai 0,583 >0,05 dan pemanfaatan internet bernilai $0,180>0,05$. Artinya masing-masing variabel tidak terjadi masalah heteroskedastisitas karena memiliki Sig $>0,05$. Semua data tersebut memenuhi syarat untuk dilakukan uji selanjutnya. Pengujian selanjutnya menggunakan analisis regresi berganda, koefisien determinasi, uji F, uji t dan uji elastisitas.

Berdasarkan hasil perhitungan analisis regresi diperoleh persamaan regresi linear berganda dalam penelitian ini adalah sebagai berikut: $Y=40,299+0,367 X_{1}+0,205 X_{2}+0,428 X_{3}$. Dari persamaantersebutdapatdiartikanbahwaNilai konstanta dalam analisis linear berganda sebesar 40,299 yang memiliki arti bahwa jika variabel manajemen kelas, kesiapan belajar dan pemanfaatan internet tidak terdapat perubahan maka prestasi belajar juga sebanyak 
40,299.Koefisien regresi $X_{1}$ yaitu 0,367 maknanya apabila manajemen kelas mendapati kenaikan satu satuan maka dapat meninggikan prestasi belajar sejumlah 0,367.

Dilihatdarihasilujisecaraparsialuntuk variabel manajemen kelas $\left(\mathrm{X}_{1}\right)$ dapat dilihat dari $t_{\text {hitung }} 3,230>t_{\text {tabel }}$ sebesar 1,66008. Nilai $t_{\text {tabel }}$ sebesar 1,66008 diperoleh dari df: $(0,05,101)$ dan memiliki signifikansi 0,002 $<0,05$ maka dapat dikatakan $H_{a}$ diterima yang artinya manajemen kelas berpengaruh positif terhadap prestasi belajar ekonomi siswa kelas X IPS SMA Negeri 4 Purwokerto.Hal ini berarti semakin baik manajemen kelas yang dilakukan oleh guru, maka semakin baik pula prestasi belajar ekonomi yang dicapai siswa. Penelitian ini membentuk suatu keyakinan yang mendukung hasil penelitian Khofifah (2016) yang meyebutkan bahwa manajemen kelas berpengaruh positif terhadap prestasi belajar siswa. Akan tetapi berbeda dengan penelitian Supriyati (2015) yang menyatakan bahwa manajemen atau kemampuan pengelolaan kelas tidak berpengaruh signifikan terhadap prestasi belajar, manajemen atau kemampuan pengelolaan kelas hanya mempengaruhi aktivitas pembelajaran.

$\mathrm{H}_{1}$ : manajemen kelas berpengaruh positif terhadap prestasi belajar

Koefisien regresi $\mathrm{X}_{2}$ sebesar 0,205 yang memiliki arti bahwa jika kesiapan belajar mengalami kenaikan satu satuan maka dapat meningkatkan prestasi belajar sebesar 0,205.Berdasarkan hasil uji hipotesis menandakan kesiapan belajar berpengaruh positif terhadap prestasi belajar pada $t_{\text {hitung }}$ sebesar 2,111 $>t_{\text {tabel }} 1,66008$ atau nilai signifikansi $0,037<0,05$ maka $H_{a}$ diterima. Hal ini berarti semakin baik kesiapan belajar yang ada di dalam diri siswa maka pencapaian prestasi belajar juga semakin baik. Hasil penelitian ini memberi dukungan atas penelitian Bujuri (2015) yang membuktikan kesiapan belajar berpengaruh positif dan signifikan terhadap prestasi belajar. Akan tetapi berbeda dengan Hotimah (2012) bahwa kesiapan belajar tidak berpengaruh terhadap prestasi belajar.

$\mathrm{H}_{2}$ : kesiapan belajar berpengaruh positif terhadap prestasi belajar

Koefisien regresi $\mathrm{X}_{3}$ sebesar 0,428 yang memiliki arti bahwa jika pemanfaatan internet mengalami kenaikan satu satuan maka dapat meningkatkan prestasi belajar sebesar 0,428. Hasil uji t menunjukkan pemanfaatan internet berpengaruh positif terhadap prestasi belajar pada $t_{\text {hitung }}$ 3,879 $>t_{\text {tabel }} 1,66008$ atau nilai signifikansi $0,000<0,05$ maka $H_{a}$ diterima Hal ini mengisyaratkan semakin baik pemanfaatan internet yang dilakukan peserta didik, maka semakin baik pula prestasi belajar yang dicapai. Dari perhitungan elastisitas dapat diketahui bahwa nilai elastisitas tertinggi adalah variabel pemanfaatan internet sebesar 0,221 . Sehingga pemanfaatan internet mempunyai pengaruh paling besar terhadap prestasi belajar ekonomi siswa kelas X IPS SMA Negeri 4 Purwokerto. Penelitian ini mendukung hasil penelitian Utami (2012) yang membuktikan pemanfaatan internet berpengaruh positif terhadap prestasi belajar. Lain halnya dengan Samiaji (2009) yang memperlihatkan bahwa pemanfaatan internet tidak berpengaruh terhadap prestasi belajar. 
$\mathrm{H}_{3}$ : pemanfaatan internet berpengaruh positif terhadap prestasi belajar

Berdasarkan pada $F_{\text {hitung }} 18,839>F_{\text {tabel }}$ sebesar 2,69 yang diperoleh dari df: 0,05, (4-1), (105-4) atau nilai signifikansi 0,000<0,05 makadapat disimpulkan manajemen kelas, kesiapan belajar dan pemanfaatan internet berpengaruh secara simultan terhadap prestasi belajar. Besarnya pengaruh manajemen kelas, kesiapan belajar dan pemanfaatan internet secara simultan terhadap prestasi belajar ekonomi siswa kelas X IPS SMA Negeri 4 Purwokerto. Hal ini berarti model penelitian dapat digunakan karena telah memenuhi uji ketepatan model.Hasil uji koefisien determinasi sebesar 34\% sehingga dapat dikatakan bahwa manajemen kelas, kesiapan belajar dan pemanfaatan internet berpengaruh secara simultan terhadap prestasi belajar ekonomi siswa kelas X IPS SMA Negeri 4 Purwokerto sebesar 34\%. Sementara itu, sebanyak 66\% prestasi belajar ekonomi dipengaruhi oleh faktor lain diluar penelitian yang tidak diamati.Manajemen kelas, kesiapan belajar dan pemanfaatan internet merupakan faktor yang dapat mempengaruhi prestasi belajar siswa. Semakin baik manajemen kelas yang dilakukan guru, semakin baik kesiapan belajar yang ada di dalam diri siswa dan semakin baik pemanfaatan internet oleh siswa maka akan semakin baik pula prestasi belajar yang diperoleh siswa.

$\mathrm{H}_{4}$ : manajemen kelas, kesiapan belajar dan pemanfaatan internet berpengaruh secara simultan terhadap prestasi belajar.

\section{KESIMPULAN}

Berdasarkan hasil penelitian, maka dapat disimpulkan:

(1) Manajemen kelas berpengaruh positif terhadap prestasi belajar ekonomi siswa kelas X IPS SMA Negeri 4 Purwokerto. (2) Kesiapan belajar berpengaruh positif terhadap prestasi belajar ekonomi siswa kelas X IPS SMA Negeri 4 Purwokerto. (3) Pemanfaatan internet berpengaruh positif terhadap prestasi belajar ekonomi siswa kelas X IPS SMA Negeri 4 Purwokerto. (4) Manajemen kelas, kesiapan belajar dan pemanfaatan internet berpengaruh secara simultan terhadap prestasi belajar ekonomi siswa kelas X IPS SMA Negeri 4 Purwokerto. Dari kesimpulan tersebut maka implikasi dari penelitian ini adalah (1)Guru selayaknya dapat menguasai manajemen kelas agar siswa dapat belajar dengan baik dan siap untuk menerima materi pelajaran dan memperhatikan pemanfaatan internet yang dilakukan siswa dalam rangka mencapai keberhasilan belajar. (2) Siswa diharapakan dapat meningkatkan kesiapan belajar dalam dirinya sehingga dapat mengikuti pembelajaran dengan baik serta melakukan pemanfaatan internet dengan baik untuk kepentingan pembelajaran (3) Sekolahdiharapkan dapat mempertahankan dan meningkatkan fasilitas internet sebagai salah satu sumber belajar untuk meningkatkan prestasi belajar siswa. (4) Peneliti selanjutnyahendaknya melakukan penelitian dengan mengimbuhkan variabel lain yang diindikasikan memberi pengaruh terhadap prestasi belajar 
seperti kelelahan, kematangan dan latar belakang kebudayaan, sehingga dapat menambah khazanah penelitian.

\section{DAFTAR PUSTAKA}

Bujuri, A. P. (2015). Pengaruh Motivasi Belajar dan Kesiapan Belajar Terhadap Prestasi Belajar Geografi SMA Swadhipa. JPG (Jurnal Penelitian Geografi). 3(1). 1-14.

Departemen Pendidikan Nasional. (2008). Kamus Besar Bahasa Indonesia (Edisi Keempat). Jakarta: PT Gramedia Pustaka Utama.

Djamarah, Syaiful Bahri dan Aswan Zain. (2010). Strategi Belajar Mengajar. Jakarta: Rineka Cipta.

Halik, Abdul. (2013). Komunikasi Massa. Makassar: Alauddin University Press.

Hotimah, Sayyimatul. (2012). Pengaruh Kesiapan Belajar Terhadap Prestasi Belajar Siswa Pada Pembelajaran Matematika di MTS Kapetakan Cirebon. Tersedia dari Repository IAIN Syekh Nurjati Cirebon. Skripsi. (repository.syekhnurjati.ac.id/974/).

Ibrahim, R dan Nana Syaodih Sukmadinata. (2010). Perencanaan Pengajaran. Jakarta: PT Rineka Cipta.

Karwati, Euis dan Donni Juni Priansa. (2014). Manajemen Kelas. Bandung: Alfabeta.

Khofifah, N. (2016). Pengaruh Manajemen Kelas dan Keaktifan Belajar Terhadap Prestasi Belajar Siswa Kelas Tinggi SD Negeri Tunjungsari Tahun Ajaran 2015/2016. Jurnal. Tersedia dari Electronic Theses and Dissertations Universitas Muhammadiyah Surakarta. (eprints.ums.ac.id/46144/).

Omenka, J.E. PhD \& Otor, E.E. PhD. (2015). Influence of Classroom Management on Students' Academic Achievement in Science and Mathematics in Oju Local Government Area of Benue State. Globale Journal of Interdisciplinary Social Sciences. 4(4). 36-40.

Putra, Hernanda Dwi. (2017). Pengaruh Pembiayaan Pendidikan dan Penggunaan Internet dalam Pembelajaran Terhadap Hasil Belajar Pendidikan Agama Islam Pada Peserta Didik di SMP AL Kautsar Bandar Lampung. Skripsi. Tersedia dari Repository UIN Raden Intan Lampung. (repository.radenintan.ac.id)

Shahibi, Mohd Sazili \& Rusli, K. (2017). The Influence of Internet Usage on Student's Academic Performance. International Journal of Academic Research in Business and Social Sciences. $7(8) .873-887$.

Riyanto. (2012). Pengaruh Pemanfaatan Internet dan Motivasi Belajar Terhadap Prestasi Belajar Siswa Kelas X (Studi Kasus Pada Kompetensi Keahlian Elektronika Industri Di SMK Muda Patria Kalasan.Skripsi. Tersedia dari ePrints@UNY Lumbung Pustaka Universitas Negeri Yogyakarta. (https://eprints.uny.ac.id/8853/).

Rusman. (2013). Model-Model Pembelajaran:Mengembangkan Profesionalisme Guru. Jakarta: Rajawali Pers.

Samiaji, Meidian Sujana. (2009). Pengaruh Pemanfaatan Internet Terhadap Prestasi Belajar (Studi Kasus Mahasiswa SI Pendidikan Tata Niaga Semester Genap Tahun Akademik 2008/2009). Skripsi. Tersedia dari Karya Ilmiah Universitas Negeri Malang. 
(karya-ilmiah.um.ac.id/index.php/manajemen/article/view/3054).

Sanjaya, Wina. (2012). Media Komunikasi Pembelajaran. Jakarta: Kencana.

Santrock, John W. (2014). Psikologi Pendidikan. Jakarta: Salemba Humanika.

Slameto. (2010). Belajar dan Faktor-Faktor yang Mempengaruhinya. Jakarta: Rineka Cipta.

Sukmadinata, Nana Syaodih. (2009). Landasan Psikologi Proses Pendidikan. Bandung: PT Remaja Rosdakarya Offset.

Suliyanto.(2011). "Ekonometrika Terapan: Teori Dan Aplikasi Dengan SPSS". Edisi 1. Yogyakarta: ANDI Yogyakarta

Suliyanto. (2012). Ekonometrika Terapan: Teori \& Aplikasi dengan SPSS. Yogyakarta: ANDI.

Suliyanto. (2018). Metode Penelitian Bisnis untuk Skripsi, Tesis \& Disertasi. Yogyakarta: ANDI OFFSET.

Supriyati, I. (2015). Kemampuan Pengelolaan Kelas Dalam Aktivitas Pembelajaran dan Pengaruhnya Terhadap Prestasi Akademik Mata Pelajaran Pendidikan Agama Islam (PAI) Siswa Kelas VIII Sekolah Menengah Pertama (SMP) Negeri 2 Lebakwangi Kabupaten Kuningan. Skripsi. Tersedia dari Repository IAIN Syekh Nurjati Cirebon. (repository.syekhnurjati.ac.id/2799/).

Tim Dosen Administrasi Pendidikan Universitas Pendidikan Indonesia. (2011). Manajemen Pendidikan. Bandung: Alfabeta.

Utami, E. D. (2012). Pengaruh Pemanfaatan Internet Dan Cara Belajar Siswa Terhadap Prestasi Belajar Ekonomi Siswa Kelas VIII di Sekolah Menengah Pertama Negeri I Simo Tahun Ajaran 2011/2012. Jurnal. Tersedia dari Electronic Theses and Dissertations Universitas Muhammadiyah Surakarta. (eprints.ums.ac.id/19165/). 